2005

General Jurisprudence: A 25th Anniversary Essay

Leslie Green

Osgoode Hall Law School of York University

Source Publication:

Oxford Journal of Legal Studies. Volume 25, Issue 4 (2005), p. 565-580.

Follow this and additional works at: https://digitalcommons.osgoode.yorku.ca/scholarly_works cc) (i) $\ominus$

This work is licensed under a Creative Commons Attribution-Noncommercial-No Derivative Works 4.0 License.

Recommended Citation

Green, Leslie. "General Jurisprudence: A 25th Anniversary Essay." Oxford Journal of Legal Studies 25.4 (2005): 565-580.

This Article is brought to you for free and open access by the Faculty Scholarship at Osgoode Digital Commons. It has been accepted for inclusion in Articles \& Book Chapters by an authorized administrator of Osgoode Digital Commons. 


\section{General Jurisprudence: A 25th Anniversary Essay}

Leslie Green*

1. Law in General

Law is a parochial business whose character and content depends on local institutions, events, and understandings. Thus it is that the most learned scholar of English law can be an ignoramus about Estonian law, let alone the law of remote societies or ancient times. To call law parochial may sound like a complaint. It is not-law would be of less value were it not firmly rooted in the societies it serves. But it does raise the question of how far we can hope for a theory of law. Particular facts can be explained; but to have a theory is to have an explanation at some level of generality. It is one thing to theorize doctrines within a legal system, to develop the branches of special jurisprudence; but how far can we work out a general jurisprudence, a theory of law as such, that will apply to contracts and to constitutions, and in Estonia as much as in England? Not every project that calls itself a 'general theory' is intelligible. Back when political scientists aspired to general theories of politics, Alasdair MacIntyre mocked them with a parable about an eccentric quest for the general theory of holes. ${ }^{1}$ It was a needed warning; but in law things are not yet that dire. Modern jurisprudence does not advance a unified theory of everything that is properly called 'law', including the law of England, the moral law, de Morgan's laws, and Boyle's law. ${ }^{2}$ All the same, it does aspire to great generality, and there is the question of how even that can be done.

One answer was offered by Aristotle, who said that in addition to 'particular law', i.e. 'that which each community lays down and applies to its own members', there is also 'universal law', the principles of natural justice rationally binding on everyone apart from any local terms of association. ${ }^{3}$ That is the germ of the classical natural law tradition which maintains that the nature of law is best seen in universal law, and that we can understand particular laws as laws only in light of that. Another tradition, a positivist one, found early expression in the works of Thomas Hobbes, who held that law is everywhere the command of a sovereign to one who is under an obligation to obey. Who is sovereign and what is commanded vary, but one basic kind of 
institutional structure characterizes societies with law. As different as they are, those two traditions-both still vital-agree on one point. Hobbes says that 'the knowledge of particular laws belongeth to them that profess the study of the laws of their several countries; but the knowledge of civil law in general, to any man'. ${ }^{4}$ And in this he claims his project is no different than Aristotle's: 'my design being not to show what is law here and there, but what is law; as Plato, Aristotle, Cicero, and diverse others have done, without taking upon them the profession of the study of the law, 5

It would be understandable to have suspicions about that idea. For one thing, it sounds lazy. It suggests some kind of a priori shortcut to knowledge of the nature of law. For another, it risks vacuity: how could general truths about law be anything other than banal? In 1961 a work that owed something to both the Aristotelian and Hobbesian traditions showed one way it could be done. H.L.A. Hart's The Concept of Lawdefended a general theory that was not a priori and that, judging from the numbers who thought it worth refuting, had substantial content. Its influence, and that of its author, was pivotal in Anglophone legal theory. ${ }^{6}$ Perhaps it is not too much to say that Hart's writings and teaching made the haphazard jumble of English jurisprudence into a real subject. In the period that followed, and especially in the last 25 years, an avalanche of specialized books, journals, articles, dictionaries, handbooks, websites and conferences have turned that subject into a discipline. I do not mean that to sound celebratory. Foucault has taught us to be suspicious of disciplines: they pursue knowledge by ordering a field, constructing its objects, and organizing inquiry. This has its risks. Disciplines can sharpen boundaries that are intrinsically fuzzy; they can neglect problems they consider outwith those boundaries; they can stagnate within them. Indeed, Ronald Dworkin, whose own work was notable in shaping post-Hartian jurisprudence, came to regret that some legal theorists had, as he put it, contrived 'a discipline that can be pursued on its own with neither background experience nor training in or even familiarity with any literature or research beyond its own narrow world and few disciples' ${ }^{7}$ Harsh words. But they raise a good question, and I want to explore it here: How far has the disciplining of jurisprudence narrowed, and how far broadened, the subject? By 'the subject' I mean analytical jurisprudence in its Aristotelian and Hobbesian varieties, and the narrowing and broadening I'm interested in are collective virtues and vices of a discipline, not individual traits of any writer. My aim is not to resolve any of the outstanding 
issues - though I make no effort at neutrality — but to assess the vitality, openness, and importance of the subject.

2. The Questions Persist

Whatever else it does, a general theory of law has at its core an account of the nature of law. Hart proposed that we approach this by answering what he called three 'persistent questions' of jurisprudence: ${ }^{8}$ How are law and legal obligation related to orders backed by threats? How are they related to the requirements of morality? What are rules and what role do rules play in the law? Those are certainly not the only questions worth asking — as we shall see, one question that preoccupies our own era does not even make his list—but recent approaches to those questions might be one index of the health of the enterprise. Let me start with the good news.

\section{A. Law and Rules}

Hart said that law is a system of social rules and that every legal system includes rules that guide law's subjects, together with rules that identify, change, and apply the conduct-guiding rules, the whole thing bottoming-out in customary rules practiced by officials and actually used as standards of guidance and appraisal. It is by characterizing these uses that we explain the 'normativity' of law: normative language expresses a willingness to guide or be guided, to evaluate or be evaluated, by the rules that constitute law. Although there is no law without social rules, and therefore a degree of consensus at least among the officials, that consensus is always incomplete. Rule-application is never more than one part of adjudication, for rules inherit the indeterminacies of intention and language, so even when the law has spoken as clearly as it can manage, judges must still often exercise discretion in adapting and creating rules.

That picture remains influential, especially among positivists. But few follow it unmodified, and one of the most significant modifications came from Joseph Raz. Hart's account has the consequence that 'obligation', for example, means something different in legal contexts than it does in moral contexts. In law, it expresses a willingness to employ certain serious, categorical rules as guides to action; it expresses no commitment to the desirability of those rules. People might display this attitude for different reasons, or for none at all. Raz argued 
instead that normative language typically states reasons for acting and, in law, reasons of a special kind. Owing to a commitment I'll explain in the next section, Hart had gone overboard on the peculiarity of legal language. He failed to see that there is no special meaning of normative terms in law, there is only detachment from, or non-endorsement of, the point of view from which the judgements deploying those terms are made. ${ }^{9}$ It is therefore in a theory of reasons and practical reasoning that jurisprudence needs to be anchored.

What does jurisprudence need to know about rules? It needs to understand their logical features, their function in practical thought, and the sorts of circumstances in which they are of use. We have seen progress on all these fronts. ${ }^{10}$ Some writers thought we needed more: 'What we need is an account of how social rules... can nevertheless be bona fide reasons'. ${ }^{11}$ The word 'nevertheless' suggests a puzzle, though it does not tell us what it is. Perhaps it is the thought that there is a gap between a rule and a reason that needs to be bridged by something that makes that rule a reason. Thus some argued that rules function as reasons when they solve coordination problems, and that is why ultimate legal rules are normative. ${ }^{12}$ Or perhaps they are parts of complex cooperative intentions and it is to the theory of social action rather than the theory of games that jurisprudence should turn for help. ${ }^{13}$ Or perhaps the whole question rests on a mistake: there is no gap between rules and reasons, for rules constitute facts that can be taken and given as reasons without inquiry into their bona fides. $^{14}$

Whatever the relationship between rules and reasons, all of these theories treat social rules as nodal points of consensus. But we also have dissensus to think about. General jurisprudence is now more alert to the different sources of disagreement, ${ }^{15}$ and even within the form that Hart explored most carefully, we have a clearer understanding of the significance of vagueness or 'open-texture'. ${ }^{16}$ Not only are there always indeterminate cases, no policy can ever tame them, for it can be indeterminate whether a case is indeterminate, and thus whether it triggers the policy (which may itself not be fully determinate). A more far-reaching challenge came from Dworkin. He denied there is much agreement in law, and he thought there is lots of law, so he concluded that law cannot depend on agreement. Sometimes he put the point by saying there need be no shared 'conventions' underpinning law, which suggested that it might be enough if people shared something else, 'convictions' perhaps. ${ }^{17}$ But his considered view was more radical: law can flourish without any agreement, 
provided only there are enough (tentatively identified) legal materials for an 'interpretative attitude' to go to work. This attitude imputes an overall purpose to those materials, and then interprets their requirements in a way that tolerably fits and best justifies them in light of that purpose. No consensus is needed; indeed, 'the more we learn about law, the more we grow convinced that nothing important about it is wholly uncontroversial' ${ }^{18}$ So it is not inconceivable - it is just not very likely-that no provision of the Constitution of the United States is law in that jurisdiction. ${ }^{19}$ To put it differently, law is fixed, not by any consensus of belief, attitude or value; it is fixed by a theory. Everyone in a society - the courts, the legislatures, the peoplemight be mistaken about what their law really is, just as we were all once mistaken about the true nature of water or the shape of the earth. ${ }^{20}$ Law is not an institution built of rules, it is an attitude that builds rules when it communicates the results of the best justification. That theory may be unfamiliar or even undiscovered, for no one may yet have worked out the best justification for our practices. Depending on the nature of moral truth, there may even be law that is not only currently unknown but is unknowable to any of its actual subjects.

We have plainly come a long way from 1961. If any of these contending accounts is even close to being right, Hart's theory of the nature and role of legal rules is wrong, and wrong in fundamental ways. But the more important point is that these debates have deepened, broadened, and improved our understanding of the relationships between law and rules, or at the very least of what is at stake in our theories of the relationship. Here, legal philosophy has drawn eclectically on whatever resources seemed effective, and it has exported its results to other areas of philosophy. On our first persistent question, general jurisprudence seems in good shape.

\section{B. Law and Morality}

The position with respect to our second question is, I'm afraid, rather different. Here, jurisprudential attention and ambition has narrowed dramatically. Hart argued that there are many relationships between law and morality and that we do not understand the nature of law until we understand all of them. Morality judges law; moral attitudes shape the law; law has moral ambitions; and morality may bear on the validity of law. Hart put more energy into some of these problems than others, but what muddied the waters for later theorists was the 
fact that he also held a famous, overarching thesis about all of them. He said that none of the relationships between law and morality was necessary.

That overarching claim came to be known as the 'separability thesis' ${ }^{21}$ No other proposition in general jurisprudence has received as much attention in the last 25 years. Legal theorists debated whether it was true, whether Hart had asserted it, and whether it mattered. Some natural lawyers considered the rejection of the separability thesis the core of their position; others did not. ${ }^{22}$ Some positivists denied the separability thesis. ${ }^{23}$ Others replied that the thesis was less false than misleading, or that it had been taken out of context. ${ }^{24}$ In saying 'there is no necessary connection between law and morality' they only meant to make a claim about the possible content of a rule of recognition. Some said that was allHart had intended —after all, hadn't he allowed that every legal system necessarily has a minimum moral content and that following a rule necessarily contains 'the germ of justice'? ${ }^{25}$

The problem is not that there is no real issue here; it is that there are too many and that the separability thesis tried to solve them all at once. Two things seem (to me) clear. Hart did indeed hold the separability thesis, and he held it in its broad form. A measure of how much it mattered to him is the fact that he always resisted Raz's argument that claims of legal obligation purport to state someone's view about moral reasons for acting and that the law necessarily claims moral authority. These are very thin connections to morality, for the views and claims can be insincere or mistaken. But Hart would have none of it, and he would even flirt with Kelsenianism in order to avoid giving up the thesis that there are nonecessary relations between law and morals. ${ }^{26}$ It is clear, too, that Hart also entertained the narrower thesis, the one that contemporary jurisprudents discuss so much. He said, 'it is in no sense a necessary truth that laws reproduce or satisfy certain demands of morality, though in fact they have often done so'. ${ }^{27}$ But the denial of a necessary satisfaction relation was not his definition of the separability thesis; it was Hart's compact definition of legal positivism. Raz's theory of normativity fell afoul of the former, not the latter.

Actually, things were even worse than that, for the positivist thesis itself was further narrowed to one question: whether the fundamental conditions for the existence of law can include moral criteria. The explanation for that obsession was partly theoretical and partly polemical. Theoretically, it is of course a central issue about the 
relationship between law and morality. Just as important, however, many saw in it potential for a reply to Dworkin's strenuous arguments that moral considerations figure in legal argument in a way that cannot be explained on a positivist account. Building on earlier suggestions, W.J. Waluchow, Jules Coleman, Matthew Kramer and others argued that Dworkin was right to notice that there are moral tests for law, but wrong to suppose them necessary. ${ }^{28}$ The social conditions of legal validity are fundamental, and if they happen to provide moral tests for law then that is an interesting though merely contingent truth. In the posthumous Postscript to the Concept of Law, Hart said that was also his own view, and that it made irrelevant a number of Dworkin's criticisms. ${ }^{29}$ Even if most, or all, legal systems required moral judgment to know the law, positivists could rest easy knowing that it didn't have to be so, that 'there exists at least one conceptually possible legal system in which the criteria of validity are exclusively source- or pedigree-based ${ }^{30}$

Dworkin thought this surrendered to his own account, but the matter is not clear. The inclusivist got morality into the law via the sources: a constitution might prohibit 'cruel' punishments; a statute might require a 'fair hearing' and so on. They were not arguing from a normative ideal to a claim about law, in the manner of economists who said that the fact that a policy would be efficient shows it to be legally binding on the courts. (This is, incidentally, the only living example of the caricature of a so-called 'natural law' inference from 'ought' to 'is'.) Nor were they suggesting, with Tony Honoré, that since law claims moral rectitude it stands liable to having its claim put to the test in court, so that morality is always a persuasive source of law. ${ }^{31}$ Inclusive positivists said that morality has to enter by explicit or perhaps implicit incorporation, and that it has to bebinding, not persuasive. This was a theoretically delicate matter. First, social morality and judicial decision fix the meaning of at least some legal concepts, so the mere fact that one finds moral-sounding 'terms' in law does not show that one has found morality in the law. Homonyms are everywhere. Second, if the incorporation view were sound, it still would not follow that the courts were doing what Dworkin said they were, namely, trying to work out what morality actually requires in law. Without the interpretivist move, it might turn out that the socially incorporated moral standards are the wrong moral standards on which to base the decision in question. Suppose the law says we are to decide whether something is obscene on the basis of whether it appeals to 'prurient' interest, or to decide whether a contract is void by discovering whether it is 'meretricious'. Suppose these name moral vices and not just legal doctrines or social conventions. They may 
nonetheless be the wrong vices to worry about from the moral point of view. Dworkin's claim wasn't merely that some sort of moralizing goes on in court; it was that the moralizing is oriented toward finding out what is morally correct within the loose tether of 'fit'. It is hard to see how incorporation alone would achieve that.

The competing positivist view, that the law ends where any moralizing begins, was defended by Raz as the 'sources thesis', or what Waluchow called 'exclusive legal positivism'. ${ }^{32}$ One of Raz's arguments for drawing the line just there was based on the authoritative nature of law. All law claims legitimate authority, and it can do so only if it is the kind of thing that could have authority. The claim may be hollow-law may be unnecessary, unjust or unwise — but the claim must be intelligible. Practical authorities like law have the role of mediating between their subjects and the ultimate reasons for which those subjects should act. Authorities should base their directives on those reasons, and their authority is justified only if trying to follow their directives makes it more likely that the subjects will comply with the underlying reasons. But that is only possible if the directives can be identified in a way independent of appeal to those very reasons. Law cannot help anyone know what he ought to do if in order to know what law requires he must first figure out what he ought to do. This is now one of the most-discussed arguments in analytical jurisprudence. ${ }^{33}$ Even those not otherwise sympathetic to his views found Raz's account fruitful. ${ }^{34}$ This is not the place to test the arguments. However, many do seem to incline to Coleman's view that 'the debate between exclusive and inclusive legal positivism turns ... on the question of whether or not [moral] criteria are compatible with legal authority' ${ }^{35}$ If this is what has become of matters - and I fear that it has - it is unfortunate. Probably nothing of importance in jurisprudence turns on any single question (and it is a bit surprising to hear Coleman, the pragmatic holist, suggest otherwise.) It is easy to understand the interest in Raz's argument from authority. It puts the kind of case that philosophers like to get their teeth into: it can be crisply stated, it is conceptual in character, and it purports to have substantive conclusions. But it is not the only argument for the sources thesis, nor is rejecting it the only possible refutation. ${ }^{36}$

I don't want to suggest that everyone was fixated on that argument all the time. Legal and political philosophers - especially those working outside general jurisprudence - continued to worry about the moral limits of law, the rule of law, the duty to obey the law, and so forth. ${ }^{37}$ But those arguments were often carried 
on at some remove from theories of the nature of law, and in any event the centre of gravity in the debate about law and morality had shifted. Where Hart had seen many problems, our contemporaries tended to see one, and in doing so achieved a deeper and clearer view of a much narrower problem.

\section{Law and Coercion}

The third question is perhaps the most depressing. Here we have stasis. Hart's main interests in the relationship between law and coercive force were confined: he wanted to know whether Austin and Kelsen were right to hold that every legal norm is a coercive norm, providing or authorizing a penalty or sanction, and he wanted to know if threat of sanctions might explain the normativity of law. He returned a negative to both, and his arguments are still widely considered decisive. At their core was one central idea: all legal norms must be understood and identified 'from the point of view of those who exercise them' so the only principled way to classify rules is by the uses to which rule-users put them. ${ }^{38}$ People don't think of all legal rules as imposing sanctions because they don't use them all that way. Legal powers, 'one of the great contributions of law to social life, ${ }^{39}$ aren't used to force; they are used to facilitate. Even in criminal or tort law, the primary use of obligations is to guide conduct out of court; sanctions and civil remedies are the law's 'Plan B'. That left unresolved another question. Even if it is false that all laws are necessarily coercive, it might be true that every legal system is necessarily coercive inasmuch as every one necessarily contains some coercive norms. Joseph Raz and John Finnis showed that this too is false. We can imagine a legal system that has only 'Plan A'. Even a society of angels would have a need for law: do-gooders would still need to coordinate their activity, and there are circumstances in which they could not do so without the help of authoritative rules. ${ }^{40}$ Law is therefore not essentially a motivational device, it is essentially an informational device and the presence of sanctions in all existing legal systems is explained by features of human nature, not by any feature of law's nature.

Dissenting voices were few. Grant Lamond plausibly argued that existence of coercion in the law does not reduce to the question whether law necessarily provides sanctions; there may be less direct ways in which coercion features. Doesn't every legal system, even an angelic one, necessarily claim authority to deploy coercion should the need arise $?^{41}$ In a way reminiscent of Kelsen, ${ }^{42}$ Dworkin said that there is a necessary 
connection between law and enforcement. Wherever there is law there is a prima facie justification for the official application of force, though in Dworkin's view that justification is not mere legal authorization, but moral rectitude: 'law insists that force not be used or withheld ... except as licensed or required by individual rights and responsibilities flowing from past political decisions about when collective force is justified' ${ }^{43}$ The view of law as coercion-licenser overlaps with traditional views about the rule of law; it goes beyond them in requiring prior decisions, not only when coercion is to be deployed, but also when coercion is not to be deployed ('used or withheld'). If that sounds impossibly stringent, recall that there may be a Dworkinian 'past political decision' even if there was, in the past, no event that anyone understood to have constituted such a decision; this too is a matter for interpretation. Dworkin advanced the coercion-licenser view tentatively and without argument, though he considered it a rough 'plateau' of agreement about the function of law, a feature of law's 'force' that any theory of law's 'grounds' would need to explain. Some who agreed that law has a special function dissented on its nature. Jeremy Waldron said 'the point of law is to enable us to act in the face of disagreement'; Michael Moore said law is a justice-doer; and John Finnis said it is a common-goodachiever. ${ }^{44}$ And many others got off the train at the first stop, with Weber, Kelsen, and Hart who said it is a mistake to think of law as having any sort of distinctive function, let along the function of coercion-licensing.

Few legal theorists of any stripe paused to ask why we should care about the relationship between law and coercion. Anyone not working in general jurisprudence will have one ready answer: law embodies political power, and coercion is the hard edge of power. That invites the query whether in law there might also be soft power. If we are thinking of the sort of rules that gave grief to the coercion theorists, the formation rules for contracts, say, and we ask 'are these complete rules with distinctive functions?' we may be inclined to answer with Hart, 'yes'. But if we ask instead 'is the importance of these rules fully explained by the facilities they provide individuals?' then we may answer with Kelsen, 'no'. Complete-in-themselves rules are capable of functioning together with other, coercive, legal rules and with coercive non-legal norms in a system of social power. Questions of who gets the power to contract, what that power allows, what are the un-contracted default arrangements etc., though they raise no direct question of coercion do raise the broader question of which our interest in coercion is only one aspect: who has power to do what? My guess is that students of general jurisprudence avoid these problems as too particular and too empirical. But there may be general 
features of all voluntary powers; for example, they put control in the hands of those who have the capacity to exercise their will, which is a large but proper subset of the human population. Various legal theorists expressed the wish that general jurisprudence would both learn more from, and contribute more to, social theory. ${ }^{45}$ The relationship between law and power might have been one point of contact. Certainly there was good conceptual work on which to build. ${ }^{46}$ But it is not only analytical jurisprudence that dropped the ball; neither was there discussion of power in other branches of legal theory where one might expect it. ${ }^{47}$ There were, it is true, those who tried to make something of Michel Foucault's remark that power is 'a productive network which runs through the whole social body', on the basis of which he avers 'What we need ... is a political philosophy that isn't erected around the problem of sovereignty, nor therefore around the problems of law and prohibition. We need to cut off the King's head'. ${ }^{48}$ As far as I know, Foucault never read Hart, so the news of regicide may never have reached him. But the rest of us have no excuse. We have known for half a century why law must be more than sovereignty and prohibition, and how its social influence is not merely regulative but constructive. We have known that there are legal rules that do not coerce and that law has noncoercive functions. That we have moved such little distance from that starting gate is somewhat disappointing.

\section{The Methodological Turn}

The record, then, is mixed: we have had some broadening, some narrowing, some deepening, and some paralysis. What we have not had is convergence. All of the 'persisting questions' persist and although some mistakes have been put behind us there remain fundamental disagreements about the nature of law. Some of this may be obstinacy or invincible ignorance; some, mutual misunderstanding. An increasingly popular explanation, however, and one that marks our period, puts it down to methodology. To the questions we inherited we now add: How should one do jurisprudence?

Our language is flexible enough to permit all sorts of grammatically sound claims about law. But this is not the solution; it is the problem. Without constraints there will be no difference between a legal theory that is correct and one that is merely consistent. But which constraints? The Concept of Law was not a methodologically selfconscious book. It displayed but did not defend the conviction that a theory of law should be true to the selfunderstandings of law-users. It deployed methods of linguistic philosophy tactically, to win small battles over 
terms like 'obligation', but it avoided a strategic assault on words like 'law' or 'legal'. (To try to discover the nature of law by discovering shared linguistic criteria for the application of 'law' would be, Hart said, 'useless'. ${ }^{49}$ ) In a casual but fateful remark he also said that the book might be thought of as some kind of 'descriptive sociology' 50

The first chapter of John Finnis's Natural Law and Natural Rights marked the beginning of the end for such loose talk. A description of something is not a random selection of facts about it; it is a selection of facts judged significant. Hart had taken the first step in focusing attention on attitudes of the law-user who takes the internal point of view. But this is unstable, Finnis said, for there is also a focal case of the internal point of view, and it is the viewpoint of the person who understands law's unique value in human life and for whom, therefore, law's requirements are prima facie moral obligations. The theorist cannot occupy this perspective without sharing it, and cannot share it without coming to a view about the moral value of law. Stephen Perry echoed the idea that Hart's method was unstable, though for him it did not even have a secure right to the internal point of view: a descriptive-explanatory theory of law is constantly pulled towards one of two poles: a collapse into a passive 'mirroring' of all the disorder and obscurity in the data or else to a fully external naturalistic explanation with no priority for self-understandings. ${ }^{51}$ Hart avoided those poles only because his theory was never as value-neutral as it pretended to be; better he should have openly adopted Dworkinian interpretivism. Brian Leiter saw no instability, but argued that the methods of conceptual analysis are epistemically unreliable and don't become any more reliable by becoming morally engaged. A naturalistic method is not a hazard, but the cure. ${ }^{52}$ His proposal went well beyond the weak constraint that general jurisprudence must be consistent with such naturalistic knowledge as we have. (For example, it should not refer to supernatural entities, and it should not impute to people capacities they do not have.) Leiter argued that the fundamental features of law should also be explained by a predictive social science. It was unclear whether this was expected to save any of the appearances, or whether that mattered. It seemed friendly to the existing social sciences of law, although most of those had no ambitions to produce any theory of law; they generally worked within the familiar ontology of legal institutions and norms. Moreover, when they invoked extra-legal norms they tried to ensure what social scientists call 'face validity' for their measures. An index measuring a judicial attitude such as 'liberalism', unless that is just an arbitrary label for the results of some data-reduction 
technique, should capture what we mean by the term. It should offer, one might say, a conceptual analysis of a modest sort. ${ }^{53}$ Perhaps that would be allowed. Naturalism would of course require the legal theorist to make what were often called 'metatheoretical' value judgments, assessment of theories' comparative clarity, coherence, simplicity, consilience, and so forth. So would any theory. The question was whether any further evaluations were required. Leiter was confident that we could stop there; Finnis, Dworkin and Perry thought we needed to go all the way to a full-blooded moral appraisal of legal norms and institutions. Julie Dickson, however, defended an intermediate position according to which the theorist would need to make some assessment of which aspects of law-users' self-understandings are the most important or salient for legal theory. In that measure the theorist would have to evaluate something about legal practice as constituted by those understandings, but that would not amount to an evaluation of whether they were morally good or bad practices; it would be 'indirectly evaluative'. ${ }^{4}$

Some writers suggested that values might enter legal theory in a different way, by offering pragmatic reasons for endorsing or refusing a conception of law as already structured by one of the foregoing methodologies. Versions of 'normative positivism', for example, tried to give reasons for thinking that it would be good for us to think of law as source-based. ${ }^{55}$ It might encourage clear moral thinking, or vigilance towards legal institutions. Hart and Bentham were often cited as precursors to that line of thought, but for Hart at any rate pragmatic considerations never had a stand-alone role. They either supported an independent and, he thought, sufficient theoretical argument, or they merely refuted certain misguided proposals for conceptual reform. Radbruch's suggestion, echoed in our day by Robert Alexy, ${ }^{56}$ that extremely unjust laws or regimes should not be counted as law was understood as a reformist proposal: we should narrow the concept of law in order to avoid the bad tendencies of legal positivism. Philosophers dislike arguments based on supposed 'tendencies' of a theory; but such an argument for conceptual reform is a pragmatic argument, and it can only be met with a pragmatic reply.

With few exceptions ${ }^{57}$ legal theorists continue to hope that methodological hygiene will (eventually) bring theoretical convergence. The evidence in support of this proposition is not too encouraging: in every discipline now touted as a model of methodological propriety — whether it be modest conceptual analysis, interpretive moral philosophy, or empirical social science—we see persistent disagreements. Perhaps jurisprudence will 
prove the exception, but induction suggests that we cannot count on it. Would this be a mark of failure? If legal theorists came to the view that this is not necessarily so, they would not be the first. Political theorists have long been familiar with W.B. Gallie's suggestion that some political concepts are essentially contested.$^{58}$ Dworkin, Waldron and others appealed to a similar idea to explain why conceptual disputes in jurisprudence are in part evaluative disputes. The idea that some conceptual disputes have a persuasive quality is as old as Weber's observation that words like 'democracy' and 'justice' 'are not plowshares to loosen the soil of contemplative thought; they are swords against the enemies: such words are weapons ${ }^{59}$ Of course, Weber considered that a reason to try to build social theory on more neutral territory. Gallie's view was different. We do not share value-neutral, necessary and sufficient conditions for democracy, but we do share something else, what he called 'exemplars' or paradigms of democracies, or at the very least a shared tradition of argument about democracy. These paradigms are complex, however, and it is not unreasonable for people to highlight different aspects of them as being most important. Moreover, such controversies are essential to the concept: an outbreak of consensus around the idea democracy just means majority rule would show, not that we had finally figured out the best theory of democracy, but that we lost the concept of democracy. Whether 'law' is an appraisive concept at all is, of course, in dispute. But there is little doubt that 'the rule of law' is appraisive, and it shows signs of essential contestability. It is not surprising, then, that theorists like Dworkin or Waldron who try to understand law through the concept of the rule of law (or 'legality' as Dworkin calls it) are tempted by the idea that we are all contesting competing conceptions of law. Dworkin, however, must reject Gallie's view that there are exemplars beyond serious challenge but which do not yield to any one best theory of their nature. Gallie's account was diagnostic, not therapeutic. He thought the prognosis for convergence was poor but also that controversy was benign, if not positively healthy.

4. Why Bother?

When a subject is this abstract and controversial, it is natural to be anxious about its status and utility. Legal theorists have perhaps been more complacent about this than they should be, and in the envoi to his Hart Lecture, Ronald Dworkin tries to rouse us from our dogmatic slumbers. I want to close with some reflections on his remarks. Dworkin urges that jurisprudence should be interesting, not only to more general fields like 
political theory or the philosophy of language, but also to the parochial subject of law itself. ${ }^{60}$ The upward connection is easy enough. We have seen how modern jurisprudence consumes and produces philosophically sophisticated theories of reasons, normativity, obligations, authority, vagueness, etc. and contributes to problems in political philosophy that have at their centre the nature and value of law. Making the downward connection is harder. Dworkin tries to secure it by arguing that nature of law matters because 'It matters how judges decide cases'. ${ }^{61}$ There is no Archimedean 'second-order' subject, no philosophy of law that has as its object, law. There is only law which is already a philosophical, because interpretive, subject. Law has more and less abstract aspects, and its most abstract aspect is general jurisprudence. I'll call this the continuity thesis. Adjudication matters, and the continuity thesis promises a trickle-down of its significance from adjudication to law to legal theory. Interestingly enough, Jules Coleman is sympathetic to that conclusion. He too writes, 'Jurisprudence matters because law matters, and law matters because it figures in our practical lives, ${ }^{62}$ Yet Colemanrejects the continuity thesis, and sides with the Aristotelians and Hobbesians who say that it is one thing to know what law is, another to know what the law is. But that will dam the trickle. It matters enormously in our practical lives that we are able to tell the time. Our social and economic systems rely on it; we teach children how to tell the time long before teaching them any part of the law. It therefore matters that one is able to tell what time it is; but it does not follow that it matters that one can tell what time is, for example, whether it is real, whether it had a beginning, and so on. Still, even if the continuity thesis were correct, the trickle might be no more than a drip. It may be a lawyer's prejudice to think that adjudication matters all that much, and it may be a theorist's prejudice to think that theory matters much to adjudication. Dworkin presents the hypothetical case of Mrs Sorenson who is a advancing a market-share liability theory in her lawsuit against the manufacturers of a harmful drug. He says that general theories of law are bound to disagree on whether she should win on the strength of pre-existing law, and thus on whether she should win at all. So there is no neutral ground: you are either for Mrs Sorenson or against her. Legal philosophers should therefore ‘take up philosophy's rightful burdens, and abandon the cloak of neutrality. Speak for Mrs Sorenson and for all the others whose fate depends on novel claims about what the law already is' ${ }^{63}$ It is tempting to object straightaway: it begs the question to say she is entitled to recover only if she is entitled to win on preexisting law; and if neutrality is impossible, why speak for Mrs Sorenson instead of for the defendant 
companies; and anyway why would Mrs Sorenson want a philosopher to speak for her? The points are worth pressing, but there is a larger issue. It is often said that interpretivism is judge-centred theory of law, and it is sometimes said that we might want one theory to represent how law seems to its subjects, another to represent how it seems to a judge. ${ }^{64}$ The story of Mrs Sorenson, however, suggests that in important ways interpretivism is actually an advocate-centred theory. Its ideal spectator is a lawyer. Dworkin instructs legal theorists how best to approach Britain's Human Rights Act: 'Don't tell the judges that they should exercise their discretion as they think best. They want to know how to understand the Act as law' ${ }^{65}$ Now it is true that telling someone to exercise his discretion is often not helpful advice (unless of course he would be ready to do the right thing but for the mistaken idea that he has no discretion to do it.) But there is a background issue. Who are we to be telling judges anything? Jeremy Waldron articulates one worry about that way of approaching things: when jurisprudence organizes itself as a kind of high-brow amicus curiae it undervalues the democratic ethos, and tends to forget that judges are not the only officials in a legal system, and that even a legislature can be a forum of principle. ${ }^{66}$ I have another worry. Adjudication is a special moment in the life of the law; unlike the others is necessarily distributive in character. ${ }^{67}$ It arises from a legal dispute; it is geared towards a final settlement of that dispute; and it settles it by producing a winner and a loser. Advocacy has a special role in that process: it is oriented toward winning. Little wonder then that the rhetoric of advocacy has the features it does: the lawyer puts his case in its best light, urging that there is but one right answer to the dispute and that it already favours his client. Why would we think those features should be replicated outside the special context of advocacy, and why in legal theory?

Dworkin's complaint about the small world of jurisprudence was rooted in his dim view of certain internecine disputes among legal positivists. Who but a member of the guild would find such things interesting? Any discipline risks narrowness and introversion; I've suggested some points at which this has happened in the last 25 years of general jurisprudence. But if truth be told, the lawyer's eyes are just as likely to glaze over when confronted by the discussions of moral realism or Kripke-Putnam semantics that are also commonplace in the literature. There have always been jurisprudence books that didn't discuss much law; now there are jurisprudence books that don't discuss much jurisprudence. Will plain lawyers find them interesting? Perhaps not; but we should remember that the editor of the Quarterly Review urged Charles Darwin to abandon the 
manuscript of The Origin of Species and instead write about pigeons, because 'everyone is interested in pigeons ${ }^{68}$ And perhaps we should be glad the advice was ignored.

\section{Acknowledgments}

I thank Denise Réaume for her helpful comments. 


\section{End Notes}

'Alasdair MacIntyre, 'Is a Science of Comparative Politics Possible?', in his Against the Self-Images of the Age (South Bend, Ind.: University of Notre Dame Press, 1971), 260.

${ }^{2}$ For an explanation of why not, see J. Raz, 'The Problem about the Nature of Law', in his Ethics in the Public Domain (Oxford: Clarendon Press, 1994), 196-98.

${ }^{3}$ Rhetoric, $1373 b$.

${ }^{4}$ Leviathan, ch XXV.

${ }^{5}$ Ibid.

${ }^{6}$ For a critical treatment of his leading ideas see Neil MacCormick,H. L. A. Hart (London: Edward Arnold, 1981). For a splendid biography that helps understand his influence see Nicola Lacey, A Life of H. L. A. Hart: The Nightmare and the Noble Dream (Oxford: Clarendon Press, 2004).

${ }^{7}$ Ronald Dworkin 'Thirty Years On', 115 Harvard Law Review(2002), 1679. But see in reply B. Leiter, 'The End of Empire: Dworkin and Jurisprudence in the 21st Century', 35 Rutgers Law Journal (2005) 165.

${ }^{8}$ H. L. A. Hart, Concept of Law (2nd ed, eds J. Raz and P. Bulloch) (Oxford: Clarendon Press, 1994), 6-13.

${ }^{9}$ J. Raz, Practical Reason and Norms (Oxford: Clarendon Press, 1991) 170-77; Ethics in the Public Domain:

Essays in the Morality of Law and Politics (Oxford: Clarendon Press, 1994), especially chs 10, 11.

${ }^{10}$ On these issues see the items by Raz in n 9; J. Gardner and T. Macklem, 'Reasons' in J. Coleman and S. Shapiro (eds), Oxford Handbook of Jurisprudence and the Philosophy of Law, 440-75; F. Schauer, Playing by the

Rules (Oxford: Clarendon Press, 1991) and L. Alexander and E. Sherwin, The Rule of Rules (Durham NC: Duke

University Press, 2001).

${ }^{11}$ J. Coleman, The Practice of Principle (Oxford: Clarendon Press, 2000), 86.

${ }^{12}$ G. Postema 'Co-ordination and Convention at the Foundations of Law,' 11 Journal of Legal Studies (1982) 165;

J. Coleman 'Negative and Positive Positivism' 11 Journal of Legal Studies (1982), 139. For criticism see L. Green, 'Positivism and Conventionalism', 12 Canadian Journal of Law and Jurisprudence (1999), 35-52.

${ }^{13}$ S. Shapiro 'Law, Morality and the Guidance of Conduct' (2000) 6Legal Theory.

${ }^{14}$ A. Marmor, Positive Law and Objective Values (Oxford: Clarendon Press, 2001), ch 1.

${ }^{15}$ See J. Waldron 'Vagueness in Law and Language: Some Philosophical Issues', 82 California Law

Review (1994), 509.

${ }^{16} \mathrm{~T}$. Endicott, Vagueness in Law (Oxford: Clarendon Press, 2000 ). For a sceptical view of the relevance of philosophical theories of vagueness to the law see S. Schiffer 'A Little Help from Your Friends?' (2001) 7 Legal Theory 421-31; K. Greenawalt 'Vagueness and Judicial Responses to Indeterminacy' (2001) 7 Legal Theory 43345.

${ }^{17}$ R. Dworkin, Law's Empire (Cambridge, MA: Harvard University Press, 1986), 136-7.

${ }^{18}$ Ibid, 10.

${ }^{19}$ See Timothy Endicott, 'Herbert Hart and the Semantic Sting' in J. Coleman (ed.), Hart's Postscript (Oxford:

Clarendon Press, 1996), 53-5.

${ }^{20}$ N. Stavropoulous, Objectivity in Law (Oxford: Clarendon Press, 1996); Dworkin, 'Hart's Postscript and the Character of Political Philosophy' (2004) 24 OJLS 13.

${ }^{21}$ I think the label is originally due to J. Coleman, 'Negative and Positive Positivism', 11 Journal of Legal Studies (1982), 139.

${ }^{22}$ R. Alexy, The Argument From Injustice: A Reply to Legal Positivism (Oxford: Clarendon Press, 2002), 20. But contrast J. Finnis, 'The Truth in Legal Positivism' in R.P. George (ed.), The Autonomy of Law: Essays on Legal Positivism (Oxford: Clarendon Press, 1996), 203-05.

${ }^{23}$ J. Raz, Practical Reason and Norms, 165-70; J. Gardner, 'Legal Positivism: 5 Myths', 46 American Journal of Jurisprudence (2001), 222-23; L. Green, 'Legal Positivism', Stanford Encyclopedia of Philosophy(Spring 2003). ${ }^{24}$ J. Coleman, The Practice of Principle, 104; M. H. Kramer, 'On The Separability of Law and Morality', 14 Canadian Journal of Law and Jurisprudence (2004), 315-35; J. Morauta, 'Three Separation Theses', 23 Law and Philosophy (2004), 111-35.

${ }^{25}$ Hart, Concept of Law, 193-200, 206.

${ }^{26}$ H. L. A. Hart, Essays on Bentham (Oxford: Clarendon Press, 1982), 267.

${ }^{27}$ Concept of Law, 185-86. 
${ }^{28}$ W. J. Waluchow, Inclusive Legal Positivism (Oxford: Clarendon Press, 1999); J. Coleman, The Practice of Principle (Oxford: Clarendon Press, 2001); M. Kramer, Law Without Trimmings (Oxford: Clarendon Press, 1994).

${ }^{29}$ Concept of Law, 250-54.

${ }^{30}$ K. E. Himma, 'Inclusive Legal Positivism', in J. Coleman and S. Shapiro, Oxford Handbook of Jurisprudence and Legal Philosophy, 136.

${ }^{31} \mathrm{~T}$. Honoré, 'The Necessary Connection between Law and Morality' (2002) 22 OJLS 489-95.

${ }^{32} \mathrm{~J}$. Raz, Ethics in the Public Domain, ch 10; J. Raz, Morality of Freedom, ch 3.

${ }^{33}$ The literature is enormous. For a beginning, see W. J. Waluchow, Inclusive Legal Positivism, A.

Marmor, Positive Law and Objective Values (Oxford: Clarendon Press, 2000), 49-70; J. Coleman, Practice of

Principle, R. Dworkin, 'Thirty Years On'; S. Shapiro, 'Law, Morality and the Guidance of Conduct'.

${ }^{34}$ J. Finnis, Natural Law and Natural Rights, 233-7; J. Waldron, 'Authority for Officials' in L. H. Meyer, S. L.

Paulson and T. W. Pogge (eds), Rights Culture and the Law (Oxford: Clarendon Press, 2003) 45-69.

${ }^{35} \mathrm{~J}$. Coleman, The Practice of Principle, 68.

${ }^{36}$ For some other relevant considerations see, Raz, Authority of Law (Oxford: Clarendon Press, 1979) ch 3 and L. Green, 'Legal Positivism' above n 23.

${ }^{37}$ For discussion of the recent literature on political obligation, see L. Green, 'Law and Obligation' in J. Coleman and S. Shapiro (eds), Oxford Handbook.

${ }^{38}$ Concept of Law, 41.

${ }^{39}$ Concept of Law, 28.

${ }^{40}$ Raz, Practical Reason and Norms, 154-62; Finnis, Natural Law and Natural Rights, 266-70.

${ }^{41}$ G. Lamond, 'The Coerciveness of Law' (2000) 20 OJLS 39-62; G. Lamond 'Coercion and the Nature of Law' (2001) 7 Legal Theory 35-57.

${ }^{42}$ Dworkin also agrees with Kelsen that are that there are no gaps in the law, and that legal norms are primarily directed at the courts. I cannot explore these similarities here.

${ }^{43}$ Law's Empire, 93.

${ }^{44}$ J. Waldron, Law and Disagreement (Oxford: Clarendon Press, 1999), 7; Michael Moore, 'Law as a Functional Kind' in R. George (ed),Natural Law Theory, 188-242, Finnis, Natural Law and Natural Rights, 245-52.

${ }^{45}$ M. Krygier, "'The Concept of Law” and Social Theory' (1982) 2OJLS, 155-80; B.Z. Tamanaha, 'Socio-Legal Positivism and a General Jurisprudence' (2001) 21 OJLS 1-32; N. Lacey, 'Analytical Jurisprudence and Descriptive Sociology Revisited', Texas Law Review, forthcoming.

${ }^{46}$ See, e.g. S. Lukes, Power: A Radical View.

${ }^{47}$ There is no analysis of power in Hugh Collins, Marxism and Law(Oxford: Oxford University Press, 1984), nor in Duncan Kennedy, A Critique of Adjudication (Cambridge, MA: Harvard University Press, 1997), nor in the 1,139 pages of R. Unger's, Politics, a Work in Constructive Social Theory, 3 vols. (Cambridge MA: Harvard University Press, 1987).

${ }^{48}$ M. Foucault, Power/Knowledge: Selected Interviews and Other Writings 1972-77, C. Gordon (ed.) (New York: Pantheon Books, 1980), 121.

${ }^{49}$ Hart, Concept of Law, 7, pace Dworkin, Law's Empire, 31.

${ }^{50}$ Hart, Concept of Law, v.

${ }^{51}$ S. R. Perry, 'Hart's Methodological Positivism' in J. Coleman (ed.),Hart's Postscript, 328; see also S. R. Perry, 'Interpretation and Methodology in Legal Theory' in A. Marmor (ed.), Law and Interpretation: Essays in Legal Philosophy (Oxford: Clarendon Press, 1995), 97-135.

${ }^{52}$ B. Leiter 'Rethinking Legal Realism: Toward a Naturalized Jurisprudence', 76 Texas Law Review 267 (1997); 'Legal Realism and Legal Positivism Reconsidered' (2001) 111 Ethics 278; 'Beyond the Hart-Dworkin Debate: The Methodology Problem in Jurisprudence', 48American Journal of Jurisprudence (2003), 17-51.

${ }^{53}$ See F. Jackson, From Metaphysics to Ethics: A Defence of Conceptual Analysis (Oxford: Clarendon Press, 1998). For the suggestion that Hart was engaged in no more than this, see V. Rodriguez-Blanco, 'A Defence of Hart's Semantics as Nonambitious Conceptual Analysis' (2003) 9 Legal Theory 99-124.

${ }^{54}$ J. Dickson, Evaluation and Legal Theory (Oxford: Hart, 2001); J. Dickson, 'Methodology in Jurisprudence: A Critical Survey' (2004) 10Legal Theory 117-56. I defended a related view: 'The Political Content of Legal Theory', 17 Philosophy of Social Science (1987), 1-20. 
${ }^{55}$ N. MacCormick, 'A Moralistic Case for A-Moralistic Law', 20Valparaiso Law Review 1 (1985); T.

Campbell, The Legal Theory of Ethical Positivism (Brookfield, VT: Dartmouth, 1996); S. Perry, 'Interpretation and Methodology in Legal Theory', J. Waldron, 'Normative (or Ethical) Positivism, in Hart's Postscript: Essays on the Postscript to the Concept of law, Jules Coleman (ed.) (Oxford: Clarendon Press, 2001); L. Murphy, 'The Political Question about the Concept of Law', in ibid.

${ }^{56} \mathrm{R}$. Alexy, The Argument from Injustice.

${ }^{57}$ See R. Shiner, Norm and Nature (Oxford: Clarendon Press, 1992) for one suggestion that the debate may be permanent. For another see L. Alexander and E. Sherwin, The Rule of Rules, 200-04.

${ }^{58}$ W. B. Gallie, 'Essentially Contested Concepts', 56 Proceedings of the Aristotelian Society (1955-56), 167-98.

${ }^{59}$ Max Weber, 'Science as a Vocation', in From Max Weber, H. H. Gerth and C. W. Mills (eds) (London:

Routledge, 1970), 145.

${ }^{60}$ Dworkin, 'Hart's Postscript', 37.

${ }^{61}$ Law's Empire, 1.

${ }^{62} \mathrm{~J}$. Coleman, Practice of Principle, 70.

${ }^{63}$ R. Dworkin, 'Hart's Postscript', 37.

${ }^{64}$ For a version of the duality thesis, see J. Eekelaar, 'Judges and Citizens: Two Conceptions of Law' (2002)

22 OJLS 497-516.

${ }_{65}$ 'Hart's Postscript', 37.

${ }^{6} \mathrm{~J}$. Waldron, Law and Disagreement.

${ }^{67}$ See, J. Gardner, 'The Virtue of Justice and the Character of Law' (2000) Current Legal Problems 1.

${ }^{68}$ C. Darwin Correspondence (ed F. Burkhardt) (Cambridge: Cambridge University, Press, 1991), vol. 7, 3 May 1859, letter from Whitwell Elwin to John Murray. 